Artikel Penelitian

\title{
Hubungan Antenatal Care dengan Kejadian Bayi Berat Lahir Rendah pada Ibu Aterm di RSUP Dr. M. Djamil Padang
}

\author{
Nurhayani Fatimah ${ }^{1}$, Bobby Indra Utama ${ }^{2}$, Susila Sastri ${ }^{3}$
}

\begin{abstract}
Abstrak
Bayi Berat Lahir Rendah (BBLR) dipengaruhi banyak faktor. Semua faktor dapat dicegah dan dideteksi secara dini melalui kunjungan antenatal care (ANC) yang lengkap dari segi kuantitas dan pelayanan yang berkualitas. Tujuan penelitian ini adalah menentukan hubungan antenatal care dengan kejadian bayi berat lahir rendah di RSUP Dr. M. Djamil Padang. Jenis penelitian ini merupakan studi analitik dengan desain cross sectional, dilakukan bulan Juni hingga Oktober tahun 2015. Populasi adalah rekam medik seluruh ibu hamil yang melahirkan di bagian Obstetrik dan Ginekologi RSUP Dr. M. Djamil Padang pada Januari 2013-Juni 2014. Besar sampel penelitian yang diambil adalah sebanyak 84 subjek. Data dianalisis menggunakan uji chi-square. Hasil uji statistik diperoleh, ibu yang melahirkan BBLR lebih sedikit melakukan ANC yang lengkap daripada ibu yang melahirkan bayi normal ( $p=0,026$; $\mathrm{OR}=3,692$ ). Simpulan studi ini ialah tidak ada hubungan tenaga kesehatan yang dikunjungi ibu saat ANC dengan $\operatorname{BBLR}(p=0,875)$. Frekuensi ANC ibu hamil aterm memiliki hubungan dengan kejadian BBLR. Ibu yang melakukan kunjungan ANC kurang dari 4 kali memiliki risiko 3,692 kali untuk melahirkan BBLR daripada ibu dengan kunjungan ANC yang lengkap.
\end{abstract}

Kata kunci: bayi berat lahir rendah, antenatal care

\begin{abstract}
There are a lot of factors that can be a predisposition factors to Low Birth Weight (LBW) infant such as maternal, fetal, and placental factors. In spite of, all the factors can be prevented and early-detected early through a complete Antenatal Care (ANC) visitation both good in quantity and quality. The objective of this study was to determine relationship between ANC and LBW at RSUP Dr. M.Djamil hospital. This analytical study was using as a cross sectional study and was done from June to October 2015. The population were all of medical record from pregnant women who underwent the labor in Departement of Obstetry and Gynecology of RSUP Dr. M. Djamil Padang from January 2013 to June 2014. The sample size was taken as 84 subjects. Data was analyzed using chi-square test. Statistically, the woman who gave a low birth weight newborn are less frequent doing an antenatal care visitation compared to those who gave a normal birth-weight newborn $(p=0,026$; OR=3,692). There is no relationship between the health care provider visited by a pregnant women with the incidence of low birth weight newborn $(p=0.875)$. The frequency ANC of aterm pregnant woman has a relationship to the incidence of LBW. Mothers who have less than 4 ANC visits more like to have 3,692 times risk of having infant low birth weight as compared to those who have complete visits.
\end{abstract}

Keywords: low birth weight, antenatal care

Affiliasi penulis: 1. Prodi Profesi Dokter FK Unand (Fakultas Kedokteran Universitas Andalas Padang), 2. Bagian Obstetri Ginekologi FK Unand/RSUP Dr. M. Djamil Padang, 3. Bagian Biokimia FK Unand
Korespondensi: Nurhayani Fatimah, Email:anie.deani@gmail.com, Telp: 085766510607 


\section{PENDAHULUAN}

Bayi Berat Lahir Rendah (BBLR) adalah bayi yang mempunyai berat lahir kurang dari 2.500 gram yang ditimbang pada saat lahir sampai dengan 24 jam pertama setelah lahir. ${ }^{1}$ Angka kejadian BBLR di Indonesia tahun 2012 adalah sebesar 10,2\% dan prevalensi di Sumatera Barat meningkat menjadi 7,5\% dari yang sebelumnya $6 \%$ pada tahun $2011 .^{2}$ Kejadian BBLR di kota Padang pun juga mengalami peningkatan dari 94 bayi per 16.805 lahir hidup (0,55\%) pada tahun 2012 menjadi sebanyak 171 bayi dari 17.767 lahir hidup (0,96\%) pada tahun 2013. Padahal dari tahun sebelumnya, angka BBLR justru mengalami penurunan. ${ }^{3}$

Angka tersebut memiliki arti yang bermakna karena bayi berat lahir rendah memiliki risiko morbiditas dan mortalitas yang tinggi. Semakin rendah berat badan lahir, maka makin tinggi risiko mortalitas neonatus. ${ }^{4}$ Hasil studi mortalitas Survei Kesehatan Rumah Tangga (SKRT) 2001 menunjukkan bahwa proporsi penyebab kematian neonatal tertinggi kelompok umur 0-7 hari adalah prematur dan berat badan lahir rendah (35\%). ${ }^{5}$ Kasus kematian bayi (0-12 bulan) di kota Padang tahun 2013 mengalami peningkatan dari 71 bayi menjadi 102 bayi. $^{2}$

Bayi berat lahir rendah juga memiliki risiko tinggi untuk terjadinya penyakit kardiovaskuler, penyakit metabolik saat dewasa, dan keterlambatan pertumbuhan. ${ }^{6}$ Oleh karena itu, penting untuk mengetahui faktor-faktor yang mempengaruhi BBLR seperti faktor ibu, faktor janin sendiri, dan faktor plasenta. $^{7}$ Semua faktor tersebut dapat dicegah dengan promosi kesehatan melalui kunjungan antenatal care (ANC). ${ }^{8}$ Menurut Adriaansz asuhan antenatal care adalah upaya preventif program pelayanan kesehatan obstetrik untuk optimalisasi luaran maternal dan neonatal melalui serangkaian kegiatan pemantauan rutin selama kehamilan. ${ }^{9}$ Jika ibu hamil mau melakukan pemeriksaan melalui kunjungan ANC, maka kelainan yang mungkin akan timbul cepat diketahui dan segera diatasi sebelum berpengaruh buruk pada kehamilan. Salah satu tujuan pemeriksaan kehamilan ini adalah agar bayi dapat lahir dengan tumbuh kembang secara normal. ${ }^{10}$

Permasalahan antenatal ini adalah kepatuhan ibu yang kurang terhadap kunjungannya sehingga menyebabkan kuantitas ibu melakukan ANC untuk memantau kesehatan dan kehamilan ikut mengalami penurunan, akibatnya terjadi peningkatan angka kematian ibu di Indonesia karena kehamilan risiko tinggi, komplikasi dan penyulit ibu yang tidak dapat dikontrol dan ditatalaksana dengan baik. ${ }^{11}$

Cakupan ibu hamil yang mendapatkan pelayanan kesehatan di Indonesia tahun 2012 adalah sebesar $87,18 \%$. Pencapaian di kota Padang pada tahun 2012 mengalami sedikit penurunan menjadi $92,2 \%$ dari $94 \%$ pada tahun 2011. Angka ini belum mencapai target nasional tahun 2014 yaitu $95 \% .{ }^{12}$

Kualitas pelayanan kesehatan juga turut menjadi salah satu faktor rendahnya cakupan antenatal care. Menurut Novika penurunan angka BBLR belum maksimal karena beberapa bidan belum melaksanakan upaya untuk mendeteksi dini risiko BBLR. ${ }^{13}$ Tenaga kesehatan ikut berpengaruh terhadap kualitas asuhan antenatal dalam hal kehandalan memberikan jasa yang sesuai, memberikan jaminan pelayanan yang aman dan dapat dipercaya, serta ketanggapan dalam menghadapi keluhan ibu hamil. ${ }^{14}$

lbu yang melakukan ANC kurang dari 4 kali, maka berisiko 1,15 kali lebih besar untuk melahirkan BBLR. $^{15}$ Begitu juga halnya dengan ibu yang menerima kualitas pelayanan antental yang buruk karena tidak mendapatkan pelayanan standar ANC dengan lengkap berisiko melahirkan BBLR sebesar 2,58 kali. $^{16}$

Berdasarkan uraian tersebut, terlihat bahwa antenatal care memiliki keterkaitan dengan angka kejadian BBLR. Jika ibu hamil teratur dalam kunjungannya, maka akan menurunkan angka kejadian BBLR. Data BBLR di RSUP Dr. M. Djamil Padang mengalami peningkatan dari tahun 2011 sebanyak 279 bayi dari 1243 kelahiran menjadi 456 bayi dari 1255 kelahiran pada tahun 2012. Oleh karena itu, perlu diteliti hubungan antenatal care dengan kejadian bayi berat lahir rendah di RSUP Dr. M. Djamil Padang.

\section{METODE}

Jenis penelitian ini adalah analitik observasional dengan desain cross sectional yang dilaksanakan pada Juni - Oktober 2015. Penelitian ini telah dilaksanakan di Bagian Rekam Medik RSUP Dr. 
M. Djamil Padang. Populasi adalah seluruh ibu yang melahirkan di bagian Obstetri dan Ginekologi RSUP Dr. M. Djamil Padang dari Januari 2013 - Juni 2014. Sampel penelitian sebanyak 84 subjek yang telah memenuhi kriteria inklusi dan eksklusi.

Variabel penelitian terdiri dari variabel independen yaitu frekuensi antenatal care dan kompetensi tenaga kesehatan yang dikunjungi ibu saat ANC yang mempengaruhi variabel dependen yaitu bayi berat lahir rendah. Alat yang digunakan adalah lembar pencatatan data rekam medik. Data yang terkumpul diolah, dianalisis, dan didistribusikan melalui analisis univariat dan bivariat menggunakan uji statistik chi square.

\section{HASIL}

Tabel berikut memperlihatkan distribusi frekuensi ANC dan kompetensi tenaga kesehatan yang dikunjungi ibu saat ANC.

Tabel 1. Distribusi frekuensi antenatal care ibu hamil aterm

\begin{tabular}{rcc}
\hline Variabel & Jumlah & $\begin{array}{c}\text { Persentase } \\
\mathbf{( \% )}\end{array}$ \\
\hline Frekuensi ANC & & \\
$<4$ kali & 22 & 26,2 \\
$\geq 4$ kali & 62 & 73,8 \\
\hline Jumlah & 84 & $100 \%$ \\
\hline
\end{tabular}

Pada Tabel 1 di atas dapat disimpulkan bahwa dari 84 ibu hamil aterm yang melahirkan di RSUP Dr. M. Djamil Padang pada bulan Januari 2013 hingga Juni 2014, sebanyak 62 ibu (73,8\%) memiliki frekuensi antenatal care lebih sama dari 4 kali dan 22 ibu $(26,2 \%)$ memiliki frekuensi ANC kecil dari 4 kali.

Tabel 2. Distribusi kompetensi tenaga kesehatan yang dikunjungi saat antenatal care

\begin{tabular}{lcc}
\hline \multicolumn{1}{c}{ Variabel } & Jumlah & $\begin{array}{c}\text { Persentase } \\
\mathbf{( \% )}\end{array}$ \\
\hline Perawat & 0 & 0 \\
Bidan & 72 & 85,7 \\
Dokter Umum & 0 & 0 \\
Spesialis Kandungan & 12 & 14,3 \\
\hline Jumlah & 84 & $100 \%$ \\
\hline
\end{tabular}

Hasil Tabel 2 dapat disimpulkan bahwa tenaga kesehatan yang paling banyak dikunjungi oleh ibu hamil aterm saat antenatal care adalah bidan (85,7\%) yaitu sebanyak 72 orang. Ibu yang memilih spesialis kandungan saat ANC hanya 12 orang (14,3\%). Berdasarkan hasil penelitian tidak ditemukan ibu yang melakukan kunjungan ANC ke perawat dan dokter umum.

Tabel 3. Hubungan frekuensi antenatal care dengan kejadian BBLR

\begin{tabular}{ccccccc}
\hline \multirow{2}{*}{$\begin{array}{c}\text { Frekuensi } \\
\text { ANC }\end{array}$} & \multicolumn{2}{c}{ BBLR } & \multicolumn{2}{c}{$\begin{array}{c}\text { Tidak } \\
\text { BBLR }\end{array}$} & $\mathbf{p}$ & $\begin{array}{c}\text { Odd } \\
\text { Ratio }\end{array}$ \\
\cline { 2 - 5 } & $\mathbf{f}$ & $\%$ & $\mathbf{f}$ & $\%$ & & \\
\hline$<4$ kali & 16 & 72,7 & 6 & 27,3 & & \\
$\geq 4$ kali & 26 & 41,9 & 36 & 58,1 & 0,026 & 3,692 \\
Jumlah & 42 & 50,0 & 42 & 50,0 & & \\
\hline
\end{tabular}

Berdasarkan Tabel 3 didapatkan bahwa dari 22 ibu yang memiliki kunjungan ANC kurang dari 4 kali, 16 ibu $(72,7 \%)$ melahirkan bayi berat lahir rendah dan 6 ibu $(27,3 \%)$ tidak melahirkan bayi berat lahir rendah. Sedangkan dari 62 ibu yang memiliki kunjungan ANC sama atau lebih dari 4 kali, 26 ibu (41,9\%) melahirkan BBLR dan 36 ibu $(58,1 \%)$ tidak melahirkan BBLR.

Hasil uji statistik dengan menggunakan chi square diperoleh nilai $p=0,026(p<0,05)$. Berdasarkan hasil tersebut dapat disimpulkan secara statistik bahwa terdapat hubungan yang bermakna antara frekuensi ANC dengan kejadian bayi berat lahir rendah. Odd's ratio adalah 3,692 (OR>1) sehingga dapat disimpulkan ibu hamil dengan kunjungan ANC kurang dari 4 kali memiliki risiko 3,692 kali untuk melahirkan BBLR dibandingkan ibu dengan kunjungan ANC $\geq 4$ kali.

Tabel 4. Hubungan kompetensi tenaga kesehatan yang dikunjungi ibu saat ANC dengan BBLR

\begin{tabular}{lcccccc}
\hline \multirow{2}{*}{$\begin{array}{c}\text { Tenaga } \\
\text { Kesehatan }\end{array}$} & \multicolumn{2}{c}{ BBLR } & \multicolumn{2}{c}{$\begin{array}{c}\text { Tidak } \\
\text { BBLR }\end{array}$} & p & $\begin{array}{l}\text { Odd's } \\
\text { Ratio }\end{array}$ \\
\cline { 2 - 5 } & $\mathbf{f}$ & $\%$ & $\mathbf{f}$ & $\%$ & & \\
\hline Bidan & 38 & 52,8 & 34 & 47,2 & & \\
$\begin{array}{l}\text { Spesialis } \\
\text { Kebidanan }\end{array}$ & 4 & 33,3 & 8 & 66,7 & 0,875 & 2,235 \\
Jumlah & 42 & 50,0 & 42 & 50,0 & & \\
\hline
\end{tabular}


Berdasarkan Tabel 4 didapatkan bahwa dari 72 ibu yang melakukan ANC ke tenaga kesehatan bidan, 38 ibu $(52,8 \%)$ melahirkan BBLR dan 34 ibu $(47,2 \%)$ tidak melahirkan BBLR. Sedangkan dari 12 ibu yang yang melakukan ANC ke dokter spesialis kebidanan, 4 ibu $(33,3 \%)$ melahirkan BBLR dan 8 ibu $(66,7 \%)$ tidak melahirkan BBLR.

Hasil uji statistik menggunakan chi-square diperoleh nilai $p=0,875(p>0,05)$. Berdasarkan hasil tersebut dapat disimpulkan secara statistik bahwa tidak terdapat hubungan yang bermakna antara kompetensi tenaga kesehatan yang dkunjungi ibu saat ANC dengan bayi berat lahir rendah.

\section{PEMBAHASAN}

Antenatal care (ANC) adalah pelayanan kesehatan yang diberikan oleh tenaga kesehatan untuk ibu selama kehamilannya dan dilaksanakan sesuai dengan Standar Pelayanan Kebidanan (SPK). Standar pelayanan ini dianjurkan guna menjamin perlindungan terhadap ibu atau janin, deteksi faktor risiko, dan pencegahan serta penangangan dini komplikasi kehamilan. Berdasarkan hasil penelitian pada Tabel 1, didapatkan persentase frekuensi kunjungan antenatal care ibu hamil $\geq 4$ kali lebih banyak yaitu sebesar $73,8 \%$. Hal ini diperkuat oleh penelitian yang dilakukan Amalia pada tahun 2011 di RSU Dr. MM Dunda Limboto Kabupaten Gorontalo yang menunjukkan persentase frekuensi ANC $\geq 4$ kali lebih besar yaitu $68,6 \% .{ }^{17}$ Hasil penelitian ini menunjukkan bahwa sebagian besar frekuensi kunjungan ANC ibu hamil sudah baik dan sejalan dengan program pemerintah yang menganjurkan ANC minimal 4 kali selama kehamilan. ${ }^{12}$

Pada Tabel 2, didapatkan tenaga kesehatan yang terbanyak dikunjungi ibu hamil saat antental care adalah bidan yaitu sebesar $85,7 \%$. Hal ini tidak jauh berbeda dengan hasil penelitian Mikrajab dan Syahrianti di Posyandu Kota Mojokerto pada tahun 2013 bahwa tenaga kesehatan yang paling banyak dikunjungi saat pemeriksaan kehamilan adalah bidan Puskesmas (40,6\%). ${ }^{18}$ Hasil Riskesdas 2013 juga menunjukkan hal yang sejalan bahwa bidan merupakan tenaga kesehatan yang paling berperan (memberikan pelayanan kesehatan ibu hamil. ${ }^{19}$
Berdasarkan hasil uji statistik chi-square pada Tabel 3 didapatkan bahwa nilai $p=0,026$ yaitu $p<0,05$. Simpulan adalah bahwa ada hubungan yang bermakna antara frekuensi antenatal care dengan kejadian bayi berat lahir rendah. Hasil penelitian ini sejalan dengan penelitian oleh Kumendong et al di RSU Pancaran Kasih Manado tahun 2015 bahwa ada hubungan yang bermakna antara frekuensi kunjungan ANC dengan berat bayi lahir $(p=0,001){ }^{20}$ Pada penelitian yang dilakukan Ernawati (2004) dengan menggunakan data Riskesdas 2010 juga menunjukkan adanya hubungan yang bermakna $(p=0,00) .{ }^{21}$ Hasil uji statistik didapatkan nilai Odd's Ratio yaitu 3,692 yang berarti ibu dengan kunjungan ANC kurang dari 4 kali memiliki risiko melahirkan BBLR sebesar 3,692 kali dibandingkan ibu dengan ANC lebih dari 4 kali. Hal ini sejalan dengan penelitian Saeni di Kabupaten Wonosobo tahun 2012 bahwa jika ibu kurang dari 4 kali melakukan ANC, maka berisiko 1,15 kali lebih besar untuk melahirkan BBLR. ${ }^{15}$

Salah satu hal yang ikut berperan menyebabkan terjadinya bayi berat lahir rendah adalah frekuensi antenatal care. Hal ini dikarenakan kunjungan antenatal care merupakan indikator penting dalam meningkatkan kewaspadaan dan pemantauan kesehatan gizi ibu selama hamil serta janin. Saat ANC, ibu akan diberikan standar pelayanan antenatal seperti penjelasan tanda komplikasi, pemeriksaan tekanan darah, gizi ibu, dan pendeteksian dini penyulit sehingga berpengaruh terhadap berat bayi yang akan dilahirkan. ${ }^{9}$

Hasil penelitian ini sesuai dengan kepustakaan diatas, dapat disimpulkan bahwa ibu hamil dengan kunjungan ANC kurang dari 4 kali akan berisiko melahirkan bayi berat lahir rendah. Hal ini bisa disebabkan oleh tidak terpantaunya penyulit, gizi, dan kesehatan ibu dan janin selama hamil sampai melahirkan sehingga menggangu pertumbuhan janin dan menyebabkan bayi lahir dengan berat rendah.

Sejumlah 62 ibu yang melakukan kunjungan ANC $\geq 4$ kali, hampir setengahnya $(41,9 \%)$ ibu melahirkan BBLR. Hal ini menunjukkan bahwa meskipun jumlah kunjungan ANC lengkap dan ibu tidak menerima pelayanan yang seharusnya didapatkan, maka akan tetap melahirkan bayi dengan 
berat rendah. Jadi, kualitas pelayanan ANC merupakan hal yang paling berperan dalam pencegahan BBLR.

Berdasarkan hasil uji statistik chi-square pada tabel 4 didapatkan bahwa nilai $p=0,875$ yaitu $p>0,05$. Ditarik kesimpulan bahwa tidak ada hubungan yang bermakna antara tenaga kesehatan yang dikunjungi ibu saat ANC dengan kejadian bayi berat lahir rendah. Hasil penelitian ini sejalan dengan hasil penelitian oleh Rotua tahun 2010 di RSUD Dr. Moewardi Surakarta yang menunjukkan bahwa tidak adanya hubungan yang signifikan antara kelompok BBLR dan tidak BBLR dengan tempat sang ibu melakukan ANC $(p=0,487) .{ }^{22}$ Hasil penelitian ini bertentangan dengan hasil penelitian yang dilakukan oleh Sistiarani (2008) di RSUD Banyumas yang menyatakan bahwa ada hubungan yang bermakna antara kualitas pelayanan ANC dengan kejadian BBLR $(p=0,001 ; O R=5,85)$. Penjelasannya adalah kurangnya kualitas pelayanan yang diterima ibu disebabkan oleh tenaga kesehatan yang kurang memberikan informasi kesehatan dan penilaian risiko terjadinya BBLR. ${ }^{23}$

Penerapan standar pelayanan dalam kunjungan ANC, tenaga kesehatan yang dikunjungi ibu pun memiliki keterkaitan dengan kejadian BBLR. Hal ini berhubungan dengan kemampuan dan keterampilan bidan dalam pelayanan antenatal terkait upaya pecegahan BBLR. Pendapat ini diperkuat oleh Saefullah dkk tahun 2014 bahwa walaupun sarana prasarana kesehatan memadai dan prosedur administrasi pelayanan ANC sudah baik, tapi yang memegang peranan penting adalah kemampuan SDM kesehatan dalam mencapai kualitas pelayanan antenatal. ${ }^{24}$

Hasil penelitian ini tidak sesuai dengan pendapat diatas disebabkan oleh angka persebaran bidan yang lebih banyak daripada dokter di Indonesia. Masyarakat yang tergolong perekonomian menengah ke bawah dan berpendidikan rendah cenderung memilih bidan untuk pemeriksaan kehamilannya. Sedangkan spesialis kebidanan cenderung dipilih oleh ibu yang memiliki perekonomian di atas dan pendidikan yang tinggi. Di samping itu, hasil penelitian juga menunjukkan bahwa ibu yang mengunjungi spesialis kandungan saat ANC melahirkan BBLR sebesar $33,3 \%$. Angka ini cukup bermakna mengingat asuhan ANC langsung diberikan oleh ahli kandungan. Hal ini terjadi karena ibu hamil tersebut sebagian besar merupakan rujukan dari bidan yang memiliki penyulit dan komplikasi dalam kehamilan. Demi menyelamatkan nyawa ibu, terkadang harus dilakukan terminasi kehamilan sehingga menyebabkan ibu melahirkan BBLR.

\section{SIMPULAN}

Terdapat hubungan antara frekuensi antental care dengan kejadian BBLR.

Tidak terdapat hubungan antara tenaga kesehatan yang dikunjungi ibu saat ANC dengan kejadian BBLR

\section{UCAPAN TERIMAKASIH}

Terima kasih kepada pihak rumah sakit, dan segala pihak yang telah membantu penulis dalam melakukan penelitian ini.

\section{DAFTAR PUSTAKA}

1. Departemen Kesehatan RI. Laporan hasil riset kesehatan dasar (Riskesdas Indonesia 2007). Jakarta: Depkes RI; 2008.

2. Dinas Kesehatan Provinsi Sumatera Barat. Laporan hasil riset kesehatan dasar Provinsi Sumatera Barat. Padang: Dinas Kesehatan Kabupaten Agam; 2013.

3. Dinas Kesehatan Kota Padang. Profil kesehatan tahun 2013. Dinas Kesehatan Kota Padang; 2013.

4. Kliegman RM. Bayi beresiko tinggi. Dalam: Behrman RE. Robert K, Ann MA, editor (penyunting). IImu kesehatan anak Nelson. Edisi ke-15. Vol 1. Jakarta: EGC; 2012. hlm.559-73.

5. Djaja S, Soemantri S. Penyebab kematian bayi baru lahir (neonatal) dan sistem pelayanan kesehatan yang berkaitan di Indonesia survei kesehatan rumah tangga (SKRT). Bul Penel Kesehatan. 2001;31(3):155-65.

6. Nazari M, Zainiyah SYS, Lye MS, Zalilah MS, Heidarzadeh M. Comparison of Maternal Characteristics in Low Birth Weight and Normal Birth Weight Infants. Eastern Mediterranean Health Journal. 2013;19(9):775-81. 
7. Xiong X, Demianczuk NN, Saunders LD, Wang FL, Frases WD, 2002. Impact of preeclampsia and gestational hypertension on birth weight by gestational age. American journal of epidemiology. 155(3):203-9.

8. Qader MAA, Badilla I, Amin RM, Ghazi HF. Influence of antenatal care on birth weight: a cross sectional study in Baghdad City, Iraq. BMC Public Health. 2012;12(2):A38.

9. Adriaansz G. Asuhan antenatal. Dalam: Saifuddin $A B$, Rachimhadhi T, Winkjosastaro $\mathrm{GH}$, editor (penyunting). Ilmu kebidanan. Jakarta: PT Bina Pustaka Sarwono Prawirohardjo; 2010.hlm.278-87.

10. Rukiyah Y, Yulianti L, Maemunah, Susilawati L, 2013. Asuhan kebidanan I. Jakarta: CV Trans Info Media; 2013.hlm. 2-10.

11. Dewik AA, Palandeng $H$, Ottay R. Gambaran pengetahuan tenaga kesehatan tentang antenatal care di Puskesmas Ranomuut Kota Manado. Jurnal e-Biomedik. 2013;1 (2):1075-80.

12. Kementerian Kesehatan RI. Pedoman pelayanan antenatal terpadu. Direktorat Jenderal Bina Kesehatan Masyarakat; 2010.hlm.1-40.

13. Novika AG. Analisis Kinerja Bidan dalam Deteksi Dini Risiko BBLR pada Pelayanan Antenatal di Wilayah Kabupaten Kulo Progo Tahun 2013 (tesis). Semarang: Fakultas Kesehatan Masyarakat Universitas Diponegoro: 2013.

14. Ramadhani F. Analisis Kualitas Pelayanan Terhadap Peningkatan Cakupan Antenatal Care oleh Bidan Wilayah Kerja Puskesmas Kabila Kabupaten Bone Bolango. Jurnal Masyarakat Epidemiologi Indonesia. 2014:2(2):92-7.

15. Saeni. Hubungan Antenatal Care dengan Kejadian Berat badan Lahir Rendah di Kabupaten Wonosobo (tesis). Yogyakarta: Universitas Gadjah Mada; 2012.

16. Simarmata OS. Hubungan Kualitas Pelayanan Antenatal Terhadap Kejadian Bayi Berat Lahir Rendah di Indonesia (tesis). Jakarta: Fakultas
Kesehatan Masyarakat Universitas Indonesia; 2010.

17. Amalia L. Faktor Risiko Kejadian Bayi Berat Lahir Rendah di RSU Dr. MM Dunda Limboto Kabupaten Gorontalo. Jurnal Sainstek. 2011;6(3):249-60.

18. Mikrajab MA, Syahrianti. Utilisasi Pelayanan Kesehatan Ibu Hamil melalui Integrasi Program Perencanaan Persalinan dan Pencegahan Komplikasi dan Antenatal Care di Posyandu Kota Mojokerto. Buletin Penelitian Sistem Kesehatan. 2013;16(2):203-16.

19. Kementerian Kesehatan RI. Riset kesehatan dasar (Riskesdas). Badan Penelitian dan Pengembangan Kesehatan Kementerian Kesehatan RI; 2013.

20. Kumendong Lg, Kundre R, Bataha Y. Hubungan frekuensi kunjungan antenatal care dan status gizi ibu hamil trimester III dengan berat badan lahir bayi di RSU Pancaran Kasih SMIM Manado. Jurnal Keperawatan. 2015;3(2):1-7.

21. Ernawati F. Hubungan antenatal care (ANC) dengan berat badan lahir (analisis lanjut Riskesdas 2010). Badan Penelitian dan Pengembangan Kesehatan 2010 (diunduh 10 Desember 2014). Tersedia dari: URL: HYPERLINK http://www.grey. litbang.depkes.go.id/

22. Rotua SH. Hubungan antara frekuensi antenatal care dengan kejadian bayi berat lahir rendah berdasarkan masa kehamilan di RSUD Dr. Moewardi Surakarta (skripsi). Surakarta: Universitas Sebelas Maret; 2010.

23. Sistiarani C. Faktor maternal dan kualitas pelayanan antenatal yang beresiko terhadap kejadian berat badan lahir rendah (BBLR) studi pada ibu yang periksa hamil ke tenaga kesehatan dan melahirkan di RSUD Banyumas tahun 2008 (tesis). Semarang: Universitas Diponegoro; 2008.

24. Saefullah MA, Susiarno H, Arya IFD. Pengaruh Kualitas Pelayanan Antental Terhadap Kejadian BBLR di Kabupaten Indramayu. Jurnal Keperawatan Aisyiyah. 2014;1(2):169-81. 